\title{
ANALISIS KINERJA KEUANGAN PADA PT. BANK PEMBIAYAAN RAKYAT SYARIAH (BPRS) MUAMALAT HARKAT SUKARAJA
}

\author{
Suprotul Azwa \\ Sulisti Afriani \\ Program Studi Akuntansi Fakultas Ekonomi Universitas Dehasen Bengkulu
}

\begin{abstract}
ABSTRAK
Supratul Azwa dan Sulisti Afriani. Tujuan penelitian ini untuk mengetahui kinerja keuangan PT. Bank Pembiayaan Rakyat Syariah (BPRS) Muamalat Harkat Sukaraja. Sedangkan analisis dengan menggunakan metode kuantitatif menggunakan rasio keuangan.. Hasil penelitian menunjukkan bahwa kinerja keuangan PT. Bank Pembiayaan Rakyat Syariah (BPRS) Muamalat Harkat Sukaraja dari sisi likuiditas (rasio LDR) pada tahun 2013 sebesar 143,82\% tidak sehat dan pada tahun 2014 sebesar 99,73\% meningkat menjadi sehat. Dari sisi solvabilitas (rasio CAR) sehat, yaitu tahun 2013 sebesar 14,49\% dan 2014 sebesar 12,72\%. Sedangkan dari sisi rentabilitas kinerja keuangan bank sehat baik rasio ROA maupun BOPO. Rasio ROA tahun 2013 sebesar 4,34\% dan tahun 2014 sebesar 2,58\%. Nilai rasio BOPO tahun 2013 sebesar 51,43\% dan tahun 2014 sebesar 58,29\%, karena mampu memanfaatkan aset yang ada untuk memperoleh laba maksimal dan melakukan efisiensi biaya dengan baik.
\end{abstract}

\section{ABSTRACT}

Supratul Azwa dan Sulisti Afriani,. Purpose of this study to determine the financial performance PT. Bank Pembiayaan Rakyat Syariah (BPRS) Muamalat Harkat Sukaraja. While the analysis using quantitative methods using financial ratios. The results showed that the financial performance PT. Bank Pembiayaan Rakyat Syariah (BPRS) Muamalat Harkat Sukaraja terms of liquidity (LDR) in 2013 with a ratio of 143.82\% unwell and in 2014 with a ratio of $99.73 \%$ increased to be healthy. In terms of solvency (CAR) in 2013 with a ratio of $14.49 \%$ and 2014 with a ratio of $12.72 \%$ healthy. In terms of liquidity both ROA and BOPO healthy financial performance. Ratio ROA in 2013 with a ratio of $4.34 \%$ and in 2014 with a ratio of $2.58 \%$. Ratio BOPO in 2013 with a ratio of $51.43 \%$ and in 2014 with a ratio of $58.29 \%$, because it can utilize existing assets to obtain maximum profit and cost efficiency well.

\section{Key Words: Performance, Financial}

\section{PENDAHULUAN}

Bank merupakan salah satu lembaga keuangan yang mempunyai peranan penting di dalam perekonomian suatu negara sebagai lembaga perantara keuangan. Bank dapat dikatakan sebagai darahnya perekonomian suatu Negara. Oleh karena itu kemajuan suatu bank di suatu Negara dapat pula dijadikan ukuran kemajuan Negara yang bersangkutan. Semakin maju suatu Negara, maka semakin besar pula peranan perbankan dalam mengendalikan Negara tersebut artinya bahwa keberadaan dunia perbankan semakin dibutuhkan pemerintah dan masyarakatnya. Bank dalam Pasal 1 ayat (2) UU No. 10 Tahun 1998 tentang perubahan UU No. 7 Tahun 1992 tentang perbankan adalah badan usaha yang menghimpun dana dari masyarakat dalam bentuk simpanan dan menyalurkannya kepada masyarakat dalam bentuk kredit dan atau bentuk-bentuk lain dalam rangka meningkatkan taraf hidup rakyat banyak. Jenis bank di Indonesia dibedakan menjadi dua jenis bank, yang dibedakan berdasarkan cara penentuan harga yaitu Bank yang berdasarkan prinsip konvensional dan Bank yang berdasarkan prinsip syariah.

Perbankan syariah di Indonesia sendiri muncul pada tanggal 1 Mei 1992, yaitu sejak berdirinya PT. Bank Muamalat Indonesia Tbk (BMI). Pada awalnya bank yang menggunakan prinsip syariah masih belum mendapat perhatian yang optimal dalam tatanan industri perbankan nasional. Tetapi hingga saat ini perkembangan perbankan syariah di Indonesia juga cukup menggembirakan. Perbankan syariah memasuki sepuluh tahun terakhir, pasca perubahan Undang-Undang Perbankan yang ditandai dengan terbitnya Undang-Undang Nomor 10 tahun 1998, mengalami pertumbuhan dan perkembangan yang amat pesat. Perkembangan yang pesat itu terutama tercatat sejak dikeluarkannya ketentuan Bank Indonesia yang memberi izin untuk pembukaan bank syariah yang baru maupun pendirian Unit Usaha Syariah (UUS).

Pola bagi hasil pada bank syariah memungkinkan nasabah untuk mengawasi langsung kinerja bank syariah melalui monitoring atas jumlah bagi hasil yang diperoleh. Jumlah keuntungan bank semakin besar maka semakin besar pula bagi hasil yang diterima nasabah, demikian juga sebaliknya. Jumlah bagi hasil yang kecil atau mengecil dalam waktu cukup lama menjadi indikator bahwa pengelolaan bank merosot. 
Keadaan itu merupakan peringatan dini yang transparan dan mudah bagi nasabah. Berbeda dari perbankan konvensional, nasabah tidak dapat menilai kinerja hanya dari indikator bunga yang diperoleh.

Menurut Undang-Undang Nomor 21 tahun 2008 tentang Perbankan Syariah yang telah terbit tanggal 16 Juli 2008, maka pengembangan industri perbankan syariah nasional semakin memiliki landasan hukum yang memadai dan akan mendorong pertumbuhannya secara lebih cepat lagi. Dalam suasana perkembangan yang sangat pesat tersebut, maka perbankan syariah mempunyai potensi dan peluang yang lebih besar dalam peranannya sebagai sumber pembiayaan bagi hasil perekonomian. Masyarakat sebagai pihak yang sangat berperan, pada umumnya memiliki sikap tanggap terhadap berbagai bentuk pelayanan yang diberikan oleh masing-masing bank untuk lebih menarik simpati masyarakat. Simpati dan kepercayaan masyarakat terhadap suatu bank tidak lepas dari keadaan keuangan bank, termasuk kesehatan bank itu sendiri.

Dengan berkembangnya dunia usaha dan semakin banyaknya usaha perbankan yang besar, maka faktor keuangan mempunyai arti yang sangat penting. Oleh karena itu, penerapan prinsip-prinsip yang sehat pelaksanaan fungsi-fungsi keuangan secara baik akan sangat menunjang tercapainya tujuan perusahaan. Sebagai salah satu lembaga keuangan, bank perlu menjaga kinerjanya agar dapat beroperasi secara optimal. Kinerja (kondisi keuangan) bank adalah salah satu faktor yang harus diperhatikan oleh bank untuk bisa terus bartahan hidup.

Kinerja keuangan bank merupakan bagian dari kinerja bank secara keseluruhan. Kinerja bank secara keseluruhan merupakan gambaran prestasi yang dicapai bank dalam operasionalnya, baik menyangkut aspek keuangan, pemasaran, penghimpunan dan penyaluran dana, teknologi, maupun sumber daya manusia. Salah satu penilaian kinerja yang dapat dilakukan adalah kinerja keuangan untuk mengetahui tingkat kesehatan bank. Tingkat kesehatan bank untuk menilai kinerja ini banyak menggunakan rasio keuangan sebagai alat hitungnya. Melalui rasio keuangan yang dihitung dari laporan keuangan bank secara berkala maka dapat menunjukkan kualitas suatu bank. Laporan keuangan pada perbankan menunjukkan kinerja keuangan yang telah dicapai perbankan pada suatu waktu.

Kinerja keuangan tersebut dapat diketahui dengan menghitung rasio-rasio keuangan sehingga dapat mengetahui kinerja tersebut dengan menggunakan analisis rasio, yakni rasio likuiditas, solvabilitas, rentabilitas, dan efisiensi operasional dan Manajemen. Analisis rasio ini merupakan teknis analisis untuk mengetahui hubungan antara pos-pos tertentu dalam neraca maupun laporan rugi laba bank secara individual maupun secara bersama-sama. Aspek likuiditas yang dipakai dalam rasio perbankan dapat diketahui dengan menghitung cash ratio, banking ratio, dan loan to asset ratio. Rasio keuangan untuk mengukur solvabilitas bank dapat diketahui dengan menghitung Capital Adequacy Ratio (CAR), primary ratio, dan capital ratio. Rasio Rentabilitas dapat diketahui dengan menghitung Return On Asset (ROA), Return On Equity (ROE) dan Net Profit Margin (NPM). efisiensi operasional dapat diketahui dengan menghitung BOPO. Selain itu, analisis rasio juga membantu manajemen dalam memahami apa yang sebenarnya terjadi pada perbankan berdasarkan suatu informasi laporan keuangan baik dengan perbandingan rasio-rasio sekarang dengan yang lalu dan yang akan datang pada internal perbankan maupun perbandingan rasio perbankan dengan perbankan yang lainnya atau dengan rata-rata industri pada saat titik yang sama/perbandingan eksternal.

PT. Bank Pembiayaan Rakyat Syariah (BPRS) Muamalat Harkat Sukaraja merupakan salah satu Bank Syariah yang beroperasi di Provinsi Bengkulu dan merupakan Bank Syariah pertama yang ada di Provinsi Bengkulu. adalah bank milik swasta yang didirikan dengan maksud untuk mewujudkan masa depan gemilang melalui sinergi kemitraan yang menjembatani keragaman pertumbuhan perekonomian Indonesia di segala bidang dalam rangka meningkatkan taraf hidup rakyat yang berprinsip syariah.

Penelitian ini menggunakan pengukuran rasio keuangan perbankan yaitu rasio rentabilitas (earning ratios), rasio likuiditas (liquidity ratios), dan rasio solvabilitas (capital ratios). Pengambilan ketiga rasio keuangan tersebut adalah mempermudah melihat perkembangan kondisi keuangan bank secara periodik, rasio keuangan tersebut merupakan pengganti yang lebih sederhana dari informasi yang disajikan laporan keuangan suatu bank yang sangat rinci dan rumit, dan dengan mengukur melalui rasio rentabilitas, likuiditas dan solvabilitas, maka dapat dijadikan dasar penilaian kinerja keuangan bank.

\section{LANDASAN TEORI}

\section{Bank}

Dalam pembicaraan sehari-hari, bank dikenal sebagai lembaga keuangan yang kegiatan utamanya menerima simpanan giro, tabungan dan deposito, kemudian bank juga dikenal sebagai tempat untuk meminjam uang (kredit) bagi masyarakat yang membutuhkannya, tempat untuk menukar uang, memindahkan uang atau menerima segala macam bentuk pembayaran dan setoran seperti pembayaran listrik, telepon, air, pajak, uang kuliah dan pembayaran lainnya. 
Kata bank berasal dari bahasa Italia banca berarti tempat penukaran uang. Menurut UndangUndang Perbankan Nomor 10 Tahun 1998, bank adalah badan usaha yang menghimpun dana dari masyarakat dalam bentuk simpanan dan menyalurkannya kepada masyarakat dalam bentuk kredit dan/atau bentuk-bentuk lainnya dalam rangka meningkatkan taraf hidup rakyat banyak. Pengertian bank menurut Undang-Undang tersebut diatas menegaskan adanya beberapa hal yaitu sebagai berikut:

a. Bank adalah suatu badan usaha, bukan perorangan

b. Kegiatan bank menghimpun dana dari masyarakat dan menyalurkan kembali dana tersebut kepada masyakat.

c. Tujuan bank adalah untuk meningkatkan taraf hidup rakyat banyak, jadi bukan semata-mata mencari keuntungan.

Menurut Hasibuan (2008:2), bank adalah badan usaha yang kekayaannya terutama dalam bentuk aset keuangan (financial asset) serta bermotifkan profit dan juga sosial, jadi bukan hanya mencari keuntungan saja. Sedangkan menurut Kasmir (2012:11), pengertian bank yaitu lembaga keuangan yang kegiatan utamanya adalah menghimpun dana dari masyarakat serta memberikan jasa bank lainnya. Pengertian lain juga dijelaskan oleh Suhardjono dan Kuncoro (2006:68), bank adalah lembaga keuangan yang usaha pokoknya adalah menghimpun dana dan menyalurkan kembali dana tersebut ke masyarakat dalam bentuk kredit serta memberikan jasa-jasa dalam lalu lintas pembayaran dan peredaran uang.

\section{Bank Syariah}

Di Indonesia pelopor perbankan syariah adalah Bank Muamalat Indonesia. Berdiri tahun 1991, bank ini diprakarsai oleh Majelis Ulama Indonesia (MUI) dan pemerintah serta dukungan dari Ikatan Cendekiawan Muslim Indonesia (ICMI) dan beberapa pengusaha muslim. Bank ini sempat terimbas oleh krisis moneter pada akhir tahun 90-an sehingga ekuitasnya hanya tersisa sepertiga dari modal awal. IDB kemudian memberikan suntikan dana kepada bank ini dan pada periode 1999-2002 dapat bangkit dan menghasilkan laba.

Menurut Undang-Undang Nomor 21 tahun 2008 tentang Perbankan Syariah Indonesia, dijelaskan bahwa bank syariah adalah bank yang menjalankan kegiatan usahanya berdasarkan prinsip syariah dan menurut jenisnya terdiri atas Bank Umum Syariah dan Bank Pembiayaan Rakyat Syariah. Bank Umum Syariah (BUS) adalah bank syariah yang kegiatannya memberikan jasa dalam lalu lintas pembayaran. Sesuai dengan namanya maka prinsip yang digunakan oleh bank syariah adalah prinsip hukum Islam berdasarkan fatwa yang dikeluarkan oleh lembaga yang memiliki kewenangan dalam penetapan fatwa di bidang syariah. Adapun asasnya adalah demokrasi ekonomi dengan prinsip kehatihatian, sedangkan tujuan perbankan syariah menunjang pelaksanaan pembangunan nasional dalam rangka meningkatkan keadilan, kebersamaan, dan pemerataan kesejahteraan rakyat.

Menurut Arifin (2006:11) mengemukakan bahwa aktifitas keuangan dan perbankan syariah dapat dipandang sebagai wahana bagi masyarakat modern untuk membawa mereka paling tidak pelaksanaan dua ajaran yaitu:

a. Prinsip $\mathrm{Al}$-Ta'awun, yaitu tolong-menolong, saling membantu dan bekerjasama diantara sesama untuk kebaikan.

b. Prinsip menghindari Al-Ikhtinaz yaitu menahan uang (dana) dan membiarkannya menganggur (idle) dan tidak berputar dalam transaksi yang bermanfaat bagi masyarakat umum

Kedua prinsip di atas, merupakan penentuan dasar pikiran dari pesan Alquran dalam bidang ekonomi (perbankan syariah). Dari prinsip-prinsip tersebut dapat dipahami bahwa kekuatan penggerak utama ekonomi Islam adalah kerjasama. Bank dan nasabah diposisikan sebagai mitra usaha dalam merealisasikan bisnis sesuai dengan peran dan porsi masing-masing pihak, bukan sebagai kreditur debitur. Dalam menjalin kerjasama antara bank dan nasabah harus didasarkan kepada kepercayaan (trust), sehingga pengelolaan usaha dan penggunaan dana oleh nasabah diyakini akan memberikan keuntungan kedua belah pihak. Adapun kegiatan usaha bank umum syariah terdiri atas:

a. Menghimpun dana dalam bentuk simpanan berupa giro, tabungan, atau bentuk lainnya yang dipersamakan dengan itu berdasarkan akad wadi'ah atau akad lain yang tidak bertentangan dengan prinsip syariah.

b. Menyalurkan pembiayaan bagi hasil berdasarkan akad mudharabah, akad musyarakah, atau akad lain yang tidak bertentangan dengan prinsip syariah.

c. Menyalurkan pembiayaan berdasarkan akad qardh atau akad lain yang tidak bertentangan dengan prinsip syariah.

d. Menyalurkan pembiayaan penyewaan barang bergerak atau tidak bergerak kepada nasabah berdasarkan akad ijarah dan/atau sewa beli dalam bentuk ijarah muntahiya bittamlik atau akad lain yang tidak bertentangan dengan prinsip syariah. 
e. Melakukan pengambilalihan utang berdasarkan akad hawalah atau akad lain yang tidak bertentangan dengan prinsip syariah.

f. Melakukan usaha kartu debit dan/atau kartu pembiayaan berdasarkan prinsip syariah dan membeli, menjual, atau menjamin atas risiko sendiri surat berharga pihak ketiga yang diterbitkan atas dasar transaksi nyata berdasarkan prinsip syariah, antara lain, seperti akad ijarah, musyarakah, mudharabah, murabahah, kafalah, atau hawalah berdasarkan prinsip syariah.

g. Membeli surat berharga berdasarkan prinsip syariah yang diterbitkan oleh pemerintah dan/atau BI dan menerima pembayaran dari tagihan atas surat berharga dan melakukan perhitungan dengan pihak ketiga atau antar pihak ketiga berdasarkan prinsip syariah serta melakukan penitipan untuk kepentingan pihak lain berdasarkan suatu akad yang berdasarkan pinsip syariah.

h. Menyediakan tempat untuk menyimpan barang, surat berharga, memindahkan uang, baik untuk kepentingan sendiri maupun untuk kepentingan nasabah berdasarkan prinsip syariah dan melakukan fungsi sebagai wali amanat berdasarkan akad wakalah, memberikan fasilitas letter of credit atau bank garansi berdasarkan prinsip syariah.

i. Melakukan kegiatan lain yang lazim dilakukan di bidang perbankan dan di bidang sosial sepanjang tidak bertentangan dengan prinsip syariah dan sesuai dengan ketentuan peraturan perundangundangan.

j. Melakukan kegiatan valuta asing dan kegiatan penyertaan modal pada Bank Umum Syariah atau lembaga keuangan yang melakukan kegiatan usaha berdasarkan prinsip syariah.

k. Melakukan kegiatan penyertaan modal sementara untuk mengatasi akibat kegagalan pembiayaan dengan syarat harus menarik kembali penyertaannya dan bertindak sebagai pendiri dan pengurus dana pensiun berdasarkan prinsip syariah.

1. Melakukan kegiatan dalam pasar modal sepanjang tidak bertentangan dengan prinsip syariah dan ketentuan peraturan perundang-undangan di bidang pasar modal dan menyelenggarakan kegiatan atau produk bank yang berdasarkan prinsip syariah dengan menggunakan sarana elektronik.

m. Menerbitkan, menawarkan, dan memperdagangkan surat berharga jangka pendek, baik secara langsung maupun tidak langsung melalui pasar uang dan menyediakan produk atau melakukan kegiatan usaha bank umum syariah lainnya yang berdasarkan prinsip syariah.

\section{Laporan Keuangan Bank}

Pengguna laporan bank membutuhkan informasi yang dapat dipahami, relevan, andal dan dapat dibandingkan dengan mengevaluasi posisi keuangan dan kinerja bank serta berguna dalam pengambilan keputusan ekonomi. Pengguna juga membutuhkan informasi yang lebih baik tentang karakteristik khusus operasi bank. Pengguna, termasuk otoritas pengatur, membutuhkan informasi yang tidak tersedia untuk publik. Meskipun bank merupakan objek pengawasan dan pengawasan bank kewenangan pengaturan untuk tidak menyediakan informasi tertentu bagi masyarakat, tetapi dibutuhkan pengungkapan yang menyeluruh dan memadai agar laporan keuangan bank sesuai dengan kebutuhan pengguna, dalam batasan yang layak untuk dipenuhi oleh manajemen.

Setiap jenis usaha atau perusahaan mempunyai catatan laporan keuangan yang berguna untuk menguji dan mengetahui serta menilai kondisi dan posisi keuangan tersebut. Menurut Kasmir (2012:7), Laporan keuangan adalah laporan yang menunjukkan kondisi keuangan perusahaan pada saat ini atau dalam suatu periode tertentu. Sedangkan Analisis laporan keuangan sangat bergantung pada informasi yang diambil dari laporan keuangan. Menurut Baridwan (2007:17), laporan keuangan merupakan ringkasan dari suatu proses pencatatan. Merupakan ringkasan dari transaksi-transaksi keuangan yang terjadi selama tahun buku yang bersangkutan.

Menurut Ikatan Akuntansi Indonesia (2007:2), mendefinisikan laporan keuangan sebagai berikut: laporan keuangan merupakan bagian dari proses pelaporan keuangan. Laporan keuangan yang lengkap biasanya meliputi neraca, laporan rugi/laba, laporan perubahan posisi keuangan (yang dapat disajikan dalam berbagai cara seperti misalnya sebagai laporan arus kas atau laporan arus dana), catatan dan laporan lain serta materi penjelasan yang merupakan bagian dari laporan keuangan.

Winarni dan Sugiyarso (2006:12) mendefinisikan laporan keuangan adalah daftar ringkasan akhir transaksi keuangan organisasi yang menunjukkan semua kegiatan operasional organisasi dan akibatnya selama tahun buku yang bersangkutan. Sedangkan Sugiri dan Riyono (2008:21), laporan keuangan adalah hasil akhir dari proses akuntansi. Sebagai hasil akhir dari proses akuntansi, laporan keuangan menyajikan informasi yang berguna untuk pengambilan keputusan berbagai pihak (misalnya pemilik dan kreditor). Pendapat lain dijelaskan oleh Sadeli (2008:18), laporan keuangan adalah laporan tertulis yang memberikan informasi kuantitatif tentang posisi keuangan dan perubahan-perubahannya, serta hasil yang dicapai selama periode tertentu. 
Kesimpulan dari berbagai definisi tersebut adalah bahwa laporan keuangan pada dasarnya merupakan suatu daftar yang di dalamnya berisi ringkasan atas transaksi yang terjadi selama tahun buku yang bersangkutan yang meliputi neraca, laporan rugi/laba, dan laporan perubahan posisi keuangan. Neraca menunjukkan jumlah aktiva, kewajiban, dan modal suatu perusahaan. Laporan rugi/laba menunjukkan hasil yang telah dicapai oleh perusahaan serta biaya-biaya yang dikeluarkan selama periode tertentu, sedangkan laporan perubahan posisi keuangan menunjukkan sumber dan penggunaan atau alasan-alasan yang menyebabkan perubahan modal perusahaan.

\section{Analisis Kinerja Bank}

Menurut Totok dan Sigit (2006:22), kesehatan suatu bank dapat diartikan sebagai kemampuan suatu bank untuk melakukan kegiatan operasional perbankan secara normal maupun untuk memenuhi semua kewajibannya dengan baik sesuai dengan peraturan yang berlaku. Adapun kegiatannya meliputi kemampuan untuk menghimpun dana dari masyarakat, dari lembaga lain dan modal sendiri, kemampuan mengelola dana, kemampuan untuk menyalurkan dana ke masyarakat, kemampuan untuk memenuhi kewajiban kepada masyarakat, karyawan, pemilik modal, dan pihak lain serta pemenuhan peraturan perbankan yang berlaku.

Kinerja keuangan adalah penentuan secara periodik tampilan keuangan berdasarkan sasaran, standar dan kinerja yang telah ditetapkan sebelumnya. Mengukur kinerja keuangan menggunakan analisis keuangan karena analisis keuangan melibatkan penilaian terhadap keuangan di masa yang akan datang dan untuk menentukan keunggulan suatu kinerja. Kinerja keuangan bank dapat dinilai dari kinerja untuk tahun yang lalu maupun yang sedang berjalan dengan menganalisis laporan keuangan. Febriyani dan Zulfadin (2006:42), mengemukakan kinerja keuangan dapat diukur dengan menganalisa dan mengevaluasi laporan keuangan. Informasi posisi keuangan dan kinerja keuangan di masa lalu digunakan sebagai dasar untuk memprediksi posisi keuangan dan kinerja di masa depan dan hal-hal lain yang langsung menarik perhatian pemakai seperti pembayaran deviden, upah, perkerakan harga sekuritas dan kemampuan untuk memenuhi komitmennya ketika jatuh tempo. Sedangkan Menurut Fahmi (2011:239), kinerja keuangan adalah: suatu analisis yang dilakukan untuk melihat sejauhmana perusahaan telah melaksanakan keuangan secara baik dan benar.

Penilaian kinerja keuangan dapat dinilai dengan perhitungan rasio keuangan. Rasio keuangan yang menghubungkan dua data keuangan (laporan keuangan), yaitu neraca dan laporan laba rugi. Nilai rasio keuangan tersebut nantinya dibandingkan dengan tolok ukur yang ada. Analisis dan interprestasi nilai rasio keuangan yang telah diperoleh dapat memberikan pandangan yang lebih baik dan mendalam tentang kinerja keuangan. Menurut Abdullah (2005:120) Analisisi kinerja keuangan bank mempunyai tujuan, antara lain:

a. Untuk mengetahui keberhasilan pengelola keuangan bank terutama kondisi likuiditas, kecukupan modal, dan profitabilitas yang dicapai dalam tahun berjalan maupun tahun sebelumnya.

b. Untuk mengetahui kemampuan bank dalam mendayagunakan semua aktiva yang dimiliki dalam menghasilkan profit.

Adanya informasi yang benar dan pemahaman mengenai kinerja bank maka diharapkan kepercayaan masyarakat terhadap perbankan semakin meningkat. Perhitungan yang dilakukan untuk menganalisis kinerja keuangan bank dapat dilakukan dengan menggunakan metode umum, yaitu dengan menggunakan analisis rasio keuangan. Membandingkan nilai rasio keuangan yang diperoleh dari tahun ke tahun merupakan langkah berikutnya. Langkah ini perlu dilakukan untuk mengetahui kondisi hasil perhitungan tersebut apakah baik atau kurang baik.

Analisis dan interprestasi laporan keuangan merupakan proses untuk membantu memecahkan dan sekaligus menjawab masalah-masalah yang timbul dalam suatu organisasi perusahaan maupun organisasi yang tidak bertujuan untuk memperoleh laba. Menurut Tunggal (2009:22), menjabarkan bahwa analisis dan interprestasi laporan keuangan adalah: Suatu alat yang dapat dipergunakan untuk membuat suatu keputusan antar lain mengenai rencana-rencana perluasan perusahaan, penanaman modal (investasi) perincian sumber-sumber dana operasi perusahaan, dan lain-lain.

Menurut Harahap (2010:189), Analisa laporan keuangan terdiri dari dua kata yaitu Analisa dan Laporan Keuangan. Analisa adalah memecahkan atau menguraikan sesuatu unit menjadi berbagai unit terkecil. Sedangkan Laporan Keuangan adalah: neraca, rugi/laba, dan aruskas (dana). Kalau dua pengertian ini digabungkan, maka analisa laporan keuangan adalah: menguraikan pos-pos laporan keuangan menjadi unit informasi yang lebih kecil dan melihat hubungannya yang bersifat signifikan atau mempunyai makna antara satu dengan lainnya baik antara data kuantitatif maupun data non kuantitatif dengan tujuan untuk mengetahui kondisi keuangan lebih dalam yang sangat penting dalam proses menghasilkan keputusan yang tepat. Sedangkan Foster dalam Harahap (2010:193), analisa laporan 
keuangan adalah mempelajari hubungan-hubungan di dalam suatu set laporan keuangan pada suatu saat tertentu dan kecenderungan-kecenderungan dari hubungan ini sepanjang waktu.

Sebelum kita menganalisa laporan keuangan sangat perlu menjelaskan tujuan analisa itu sendiri. Tujuan tergantung pada prespektif pemakai laporan keuangan itu dan keinginan apa yang diharapkan oleh seorang analis laporan keuangan.

Menurut Harahap (2010:195), analisa laporan keuangan bertujuan untuk:

a. Dapat memberikan informasi yang lebih luas, lebih dalam daripada yang terdapat dari laporan keuangan biasa.

b. Dapat menggali informasi yang tidak tampak secara kasat mata (explicit) dari suatu laporan keuangan atau yang berada dibalik laporan keuangan (implicit).

c. Dapat mengetahui kesalahan yang terkandung dalam laporan keuangan.

d. Dapat membongkar hal-hal yang bersifat konsisten dalam hubungannya dengan suatu laporan keuangan baik dikaitkan dengan komponen intern laporan keuangan maupun kaitannya dengan informasi yang diperoleh dari luar perusahaan.

e. Mengetahui sifat-sifat hubungan yang akhirnya dapat melahirkan model-model dan teori-teori yang terdapat di lapangan seperti untuk prediksi, peningkatan (rating).

f. Dapat memberikan informasi yang diinginkan oleh para pengambil keputusan.

\section{Indikator Kesehatan Bank}

Kesehatan Bank merupakan kemampuan suatu bank untuk melakukan kegaiatan operasi perbankan secara normal dan mampu memenuhi semua kewajibannya dengan baik dengan cara-cara yang sesuai dengan peraturan perbankan yang berlaku. Bagi perbankan hasil akhir penilaian kesehatan perbankan tersebut dapat digunakan sebagai salah satu sarana dalam menetapkan strategi usaha di waktu yang akan datang, sedangkan bagi Bank Indonesia hasil dari penilaian kesehatan perbankan digunakan sebagai sarana penetapan dan implememtasi strategi pengawasan bank oleh Bank Indonesia. Adapun indikator kesehatan bank yaitu sebagai berikut:

a. Loan to Deposit Ratio (LDR)

LDR merupakan salah satu indikator kesehatan likuiditas bank. Penilaian likuiditas merupakan penilaian terhadap kemampuan bank untuk memelihara tingkat likuiditas yang memadai dan kecukupan manajemen risiko likuiditas. LDR paling sering digunakan oleh analis keuangan dalam menilai suatu kinerja bank terutama dari seluruh jumlah kredit yang diberikan oleh bank dengan dana yang diterima oleh bank. Menurut Dendawijaya (2005:116), LDR merupakan rasio yang digunakan untuk mengetahui seberapa jauh kemampuan bank dalam membayar kembali penarikan dana yang dilakukan nasabah dengan mengandalkan kredit yang diberikan sebagai sumber likuiditasnya. LDR dihitung dari perbandingan antara total kredit dengan dana pihak ketiga.

Pada umumnya aktivitas suatu bank diarahkan pada usaha untuk meningkatkan pendapatan dengan meminimalkan risiko. Secara konvensional banyak bank mengutamakan aktivitas perkreditan sebagai sarana mencapai tujuan tersebut, namun ternyata banyak bank yang mengalami kepailitan karenanya. Aktivitas perkreditan dapat mendominasi penggunaan dana suatu bank karena perkreditan mempengaruhi aktivitas bank, penilaian atas tingkat kesehatan bank, tingkat kepercayaan nasabah serta tingkat pencapaian laba.

b. Capital Adequacy Ratio (CAR)

CAR merupakan rasio permodalan yang menunjukkan kemampuan bank dalam menyediakan dana untuk keperluan pengembangan usaha serta menampung kemungkinan resiko kerugian yang diakibatkan dalam operasional bank. Menurut Hasibuan (2008:58), CAR adalah kebutuhan modal minimum bank dihitung berdasarkan aktiva tertimbang menurut risiko (ATMR). CAR adalah kecukupan modal yang menunjukkan kemampuan bank dalam mempertahankan modal yang mencukupi dan kemampuan manajemen bank dalam mengidentifikasi, mengukur, mengawasi, dan mengontrol risiko-risiko yang timbul yang dapat berpengaruh terhadap besarnya modal. Perhitungan CAR didasarkan pada prinsip bahwa setiap penanaman yang mengandung risiko harus disediakan jumlah modal sebesar persentase tertentu terhadap jumlah penanamannya.

c. Return On Asset Ratio (ROA)

ROA merupakan rasio yang digunakan untuk mengukur kemampuan manjemen bank dalam memperoleh profitabilitas dan mengelola tingkat efisiensi usaha bank secara keseluruhan. Menurut Prihadi (2008:68), ROA (laba atas asset), adalah mengukur tingkat laba terhadap aset yang digunakan dalam menghasilkan laba tersebut. ROA (Return on Asset), merupakan perbandingan antara laba bersih dengan total aktiva. Rasio ini digunakan untuk mengukur efektifitas bank di dalam memperoleh keuntungan secara keseluruhan. Semakin besar ROA suatu bank, maka semakin besar pula tingkat keuntungan yang dicapai bank tersebut dan semakin baik pula posisi bank tersebut dari 
penggunaan aset. Rasio ini sangat penting, mengingat keuntungan yang diperoleh dari penggunaan aset dapat mencerminkan tingkat efisiensi usaha suatu bank. Dalam kerangka penilaian kesehatan bank.

d. Rasio Biaya Operasional terhadap Pendapatan Operasional (BOPO)

BOPO disebut rasio efisiensi yang digunakan untuk mengukur kemampuan manajemen bank dalam mengendalikan biaya operasional terhadap pendapat operasional. Semakin kecil rasio ini berarti semakin efisien biaya operasional yang dikeluarkan bank. Menurut Hasibuan (2008:101), BOPO dirumuskan sebagai perbandingan/rasio biaya operasional dalam 12 bulan terakhir terhadap pendapatan operasional dalam periode yang sama.

Berikut ini indikator pengukuran kesehatan keuangan bank, seperti pada tabel 1.

\section{Tabel 1. Indikator Kesehatan Keuangan Bank}

\begin{tabular}{|l|l|l|}
\hline \multicolumn{1}{|c|}{ Rasio } & \multicolumn{1}{|c|}{ Pengukuran } & \multicolumn{1}{c|}{ Standar } \\
\hline Likuiditas & LDR $=\frac{\text { Total Kredit yang Diberikan }}{\text { Total Dana }}$ X100\% $\%$ & $\begin{array}{l}\leq 110 \%=\text { Sehat } \\
>110 \%=\text { Tidak Sehat }\end{array}$ \\
\hline Solvabilitas & CAR $=\frac{\text { Modal Bank }}{\text { Total ATMR }} 100 \%$ & $\begin{array}{l}>8 \%=\text { Sehat } \\
<8 \%=\text { Tidak Sehat }\end{array}$ \\
\hline \multirow{3}{*}{ Rentabilitas } & ROA $=\frac{\text { LabahBersih }}{\text { Total Aktiva }}$ X $100 \%$ & $\begin{array}{l}>1,5 \%=\text { Sehat } \\
<1,5 \%=\text { Tidak Sehat }\end{array}$ \\
\cline { 2 - 4 } & BOPO $=\frac{\text { Biaya Operasional }}{\text { Pendapatan Operasional }}$ X $100 \%$ & $\begin{array}{l}\leq 93,52 \%=\text { Sehat } \\
>93,52 \%=\text { Tidak Sehat }\end{array}$ \\
\hline
\end{tabular}

Sumber: Bank Indonesia, 2013

\section{Kerangka Analisis}

\begin{tabular}{|l|l|l|}
\hline $\begin{array}{l}\text { Laporan Keuangan } \\
\text { 1. Laporan Laba Rugi } \\
\text { 2. Laporan Neraca }\end{array}$ & $\rightarrow \begin{array}{l}\text { Rasio Keuangan } \\
\text { 1. LDR } \\
\text { 2. CAR } \\
\text { 3. ROA } \\
\text { 4. BOPO }\end{array}$
\end{tabular}$\longrightarrow$\begin{tabular}{|l} 
Kinerja Keuangan: \\
1. Sehat \\
2. Tidak Sehat
\end{tabular}

Gambar 1. Kerangka Analisis

Dengan mengacu pengukuran kinerja beberapa rasio LDR, CAR, ROA, BOPO, sehingga diketahui kinerja keuangan PT. Bank Pembiayaan Rakyat Syariah (BPRS) Muamalat Harkat Sukaraja tahun 2013 dan 2014.

\section{HASIL PENELITIAN DAN PEMBAHASAN}

Dari data laporan keuangan PT. Bank Pembiayaan Rakyat Syariah (BPRS) Muamalat Harkat Sukaraja baik laporan laba rugi maupun laporan neraca dapat dilakukan pengukuran kinerja keuangan dari tahun 2013-2014 dengan pendekatan rasio keuangan.

a. Loan to Deposit Ratio ( $L D R$ ), adalah rasio yang merefleksikan seberapa ekstensifnya suatu bank dalam memberikan pinjaman. Berikut ini perhitungan LDR pada PT. Bank Pembiayaan Rakyat Syariah (BPRS) Muamalat Harkat Sukaraja Tahun 2013-2014:

Tabel 2. Total Kredit dan Total Dana Tahun 2013 dan 2014 (Dalam Ribuan Rp)

\begin{tabular}{|c|c|c|}
\hline Keterangan & 2013 & 2014 \\
\hline $\begin{array}{l}\text { Kredit yang diberikan (Pembiayaan): } \\
\text { - Piutang Murabahah } \\
\text { - Ijarah } \\
\text { - Qardh } \\
\text { Total Pembiayaan }\end{array}$ & $\begin{array}{r}23.654 .656 \\
46.346 \\
7.500 \\
23.708 .502\end{array}$ & $\begin{array}{r}20.350 .644 \\
- \\
22.416 \\
20.373 .060\end{array}$ \\
\hline
\end{tabular}




\begin{tabular}{|l|r|r|}
\hline Total dana: & & - \\
- Giro & - & - \\
- Tabungan Wadiah & 204.616 & 105.774 \\
- Tabungan dan Deposito BPRS Safir & 41.805 & 42.775 \\
- Tabungan Mudharabah & 10.450 .331 & 11.363 .185 \\
- Deposito Mudharabah & 6.034 .750 & 8.917 .500 \\
\cline { 2 - 3 } Total Dana & 16.485 .081 & 20.429 .234 \\
\hline
\end{tabular}

Sumber: Lampiran 2 Diolah, 2016

Tahun 2013

$=\frac{\text { Total Kredit yang Diberikan }}{\text { Total }} 100 \%$

$=\frac{23.708 .502}{16.485 .081} \times 100 \%$

$=1,4382 \times 100 \%$

$=143,82 \%$
Tahun 2014

$$
\begin{aligned}
\text { LDR } & =\frac{\text { Total Kredit yang Diberikan }}{\text { Total Dana }} \times 100 \% \\
& =\frac{20.373 .060}{20.429 .234} \times 100 \% \\
& =0,9973 \times 100 \% \\
& =99,73 \%
\end{aligned}
$$

Dari perhitungan rasio Loan to Deposit Ratio (LDR) di atas dapat di susun tabel hasil perhitungan rasio LDR seperti pada tabel 3.

Tabel 3. Hasil Perhitungan LDR

\begin{tabular}{|l|c|c|c|}
\hline Tahun & Besarnya Rasio & Standar BI & Keterangan \\
\hline 2013 & $143,82 \%$ & $\leq 110 \%$ & Tidak Sehat \\
\hline 2014 & $99,73 \%$ & $\leq 110 \%$ & Sehat \\
\hline
\end{tabular}

Sumber: Data Diolah, 2016

Dari tabel 3 di atas bahwa kinerja keuangan PT. Bank Pembiayaan Rakyat Syariah (BPRS) Muamalat Harkat Sukaraja tahun 2013 tidak sehat, karena rasio likuiditas yaitu LDR berdasarkan standar Bank Indonesia tidak boleh melebihi 110\%. Tidak sehatnya kinerja keuangan dari perhitungan LDR karena pembiayaan atau kredit yang disalurkan tidak sebanding dengan total dana yang diterima dari masyarakat dalam bentuk giro, tabungan, dan deposito.

Sedangkan kinerja keuangan PT. Bank Pembiayaan Rakyat Syariah (BPRS) Muamalat Harkat Sukaraja dari rasio likuiditas yaitu LDR pada tahun 2014 rasio sehat karena nilai di bawah 110\%, hal ini menunjukkan bahwa pada tahun 2014 terdapat peningkatan dana yang terkumpul dari masyarakat dalam bentuk tabungan dan deposito BPRS Safir, tabungan Mudharabah dan deposito Mudharabah.

b. Capital Adequacy Ratio (CAR), adalah merupakan kemampuan dalam menyediakan dana untuk keperluan pengembangan usaha serta menampung kemungkinan resiko kerugian yang diakibatkan dalam operasional bank. Berikut ini perhitungan CAR pada PT. Bank Pembiayaan Rakyat Syariah (BPRS) Muamalat Harkat Sukaraja tahun 2013-2014:

Tabel 4. Modal Bank dan Total ATMR Tahun 2013 dan 2014 (Dalam Ribuan Rp)

\begin{tabular}{|l|r|r|}
\hline \multicolumn{1}{|c|}{ Keterangan } & 2013 & \multicolumn{1}{|c|}{2014} \\
\hline Modal Bank: & 2.055 .000 & 2.055 .000 \\
- Modal Disetor & 425.443 & 577.105 \\
- Cadangan & 1.211 .204 & 743.134 \\
- Saldo Laba (rugi) & 3.691 .647 & 3.375 .239 \\
Total Modal Bank & & \\
\hline ATMR: & 265.718 & 2.066 .152 \\
- Giro pada Bank Lain & 1.485 .500 & 4.082 .990 \\
- Penembatan pada Bank Lain & 20.000 & 20.000 \\
- Deposito pada Bank Lain & 23.654 .656 & 20.350 .644 \\
- Piutang Mudharabah & 46.346 & \\
- Ijrah & 7.500 & 22.416 \\
- Qardh & 25.479 .720 & 26.542 .202 \\
\hline Total ATMR & & \\
\hline
\end{tabular}

Sumber: data diolah, 2016 
Tahun 2013

$$
\begin{aligned}
\text { CAR } & =\frac{\text { Modal Bank }}{\text { Total ATMR }} \times 100 \% \\
& =\frac{3.691 .647}{25.479 .720} \times 100 \% \\
& =0,1449 \times 100 \% \\
& =14,49 \%
\end{aligned}
$$

Tahun 2014

$$
\begin{aligned}
\text { CAR } & =\frac{\text { Modal Bank }}{\text { Total ATMR }} \times 100 \% \\
& =\frac{3.375 .239}{26.542 .202} \times 100 \% \\
& =0,1272 \times 100 \% \\
& =12,72 \%
\end{aligned}
$$
tabel 5 .

Dari perhitungan rasio CAR di atas dapat di susun tabel hasil perhitungan CAR seperti pada

Tabel 5. Hasil Perhitungan CAR

\begin{tabular}{|c|c|c|c|}
\hline Tahun & Besarnya Rasio & Standar BI & Keterangan \\
\hline 2013 & $14,49 \%$ & $>8 \%$ & Sehat \\
\hline 2014 & $12,72 \%$ & $>8 \%$ & Sehat \\
\hline
\end{tabular}

Sumber: Data Diolah, 2016

Dari tabel 5 di atas bahwa CAR, juga menunjukkan bahwa PT. Bank Pembiayaan Rakyat Syariah (BPRS) Muamalat Harkat Sukaraja sehat karena nilai rasio berdasarkan standar Bank Indonesia harus di atas 8\% dan hasil rasio baik tahun 2013 maupun tahun 2014 di atas 8\%.

c. Return on Assets (ROA) adalah mengindikasikan kemampuan Bank untuk dapat mengkonversi asetnya menjadi pendapatan. Berikut ini perhitungan ROA pada PT. Bank Pembiayaan Rakyat Syariah (BPRS) Muamalat Harkat Sukaraja tahun 2013-2014:

Tabel 6. Laba Bersih dan Total Aktiva Tahun 2013 dan 2014 (Dalam Ribuan Rp)

\begin{tabular}{|l|r|r|}
\hline \multicolumn{1}{|c|}{ Keterangan } & 2013 & \multicolumn{1}{|c|}{2014} \\
\hline Laba Bersih & 1.211 .204 & 743.134 \\
\hline Total Aktiva & 27.886 .546 & 28.839 .739 \\
\hline
\end{tabular}

Sumber: Lampiran 1 dan 2, Diolah 2016

Tahun 2013

$$
\begin{aligned}
\text { ROA } & =\frac{\text { Laba Bersih }}{\text { Total Aktiva }} \times 100 \% \\
& =\frac{1.211 .204}{27.886 .546} \times 100 \% \\
& =0,0434 \times 100 \% \\
& =4,34 \%
\end{aligned}
$$

$$
\begin{aligned}
& \text { Tahun } 2014 \\
& \text { ROA }=\frac{\text { Laba Bersih }}{\text { Total Aktiva }} \times 100 \% \\
& =\frac{743.134}{28.839 .739} \times 100 \% \\
& =0,0258 \times 100 \% \\
& =2,58 \%
\end{aligned}
$$

Dari perhitungan rasio ROA di atas dapat di susun tabel hasil perhitungan rasio ROA seperti pada tabel 7.

Tabel 7. Hasil Perhitungan Rasio ROA

\begin{tabular}{|c|c|c|c|}
\hline Tahun & Besarnya Rasio & Standar BI & Keterangan \\
\hline 2013 & $4,34 \%$ & $>1,5 \%$ & Sehat \\
\hline 2014 & $2,58 \%$ & $>1,5 \%$ & Sehat \\
\hline
\end{tabular}

Sumber: Data Diolah, 2016

Dari tabel 7 di atas menunjukkan bahwa kinerja keuangan PT. Bank Pembiayaan Rakyat Syariah (BPRS) Muamalat Harkat Sukaraja dari perhitungan ROA masuk dalam kriteria sehat, karena persentase laba yang diperoleh dari total aktiva baik tahun 2013 maupun tahun 2014 di atas 1,5\% walaupun terjadi penurunan hasil rasio ROA dari 4,30 pada tahun 2013 menjadi 2,60 pada tahun 2014, hal ini karena terjadi penurunan laba sebesar Rp 468.070 (Rp 1.211.204-Rp 743.134).

d. Biaya Operasional terhadap Pendapatan Operasional (BOPO) merupakan rasio efeisiensi yang digunakan untuk mengukur tingkat efisiensi dan kemampuan bank dalam melakukan kegiatan operasinya. Berikut ini perhitungan BOPO pada PT. Bank Pembiayaan Rakyat Syariah (BPRS) Muamalat Harkat Sukaraja tahun 2013-2014: 
Tabel 8. Beban dan Pendapatan Operasional Tahun 2013 dan 2014

(Dalam Ribuan Rp)

\begin{tabular}{|l|r|r|}
\hline \multicolumn{1}{|c|}{ Keterangan } & 2013 & 2014 \\
\hline Pendapatan Operasional & 7.475 .641 & 7.126 .999 \\
\hline Beban Operasional & 3.845 .094 & 4.154 .197 \\
\hline
\end{tabular}

Sumber: Lampiran 2 diolah 2016

Tahun 2013

$$
\begin{aligned}
\text { BOPO } & =\frac{\text { Beban Operasional }}{\text { Pendapatan Operasional }} \times 100 \% \\
& =\frac{3.845 .094}{7.475 .641} \times 100 \% \\
& =0,5143 \times 100 \% \\
& =51,43 \%
\end{aligned}
$$

Tahun 2014

$$
\begin{aligned}
\text { BOPO } & =\frac{\text { Beban Operasional }}{\text { Pendapatan Operasional }} \text { X } 100 \% \\
& =\frac{4.154 .197}{7.126 .999} \times 100 \% \\
& =0,5829 \times 100 \% \\
& =58,29 \%
\end{aligned}
$$
pada tabel 9.

Dari perhitungan rasio BOPO di atas dapat di susun tabel hasil perhitungan rasio BOPO seperti

Tabel 9. Hasil Perhitungan Rasio BOPO

\begin{tabular}{|c|c|c|c|}
\hline Tahun & Besarnya Rasio & Standar BI & Keterangan \\
\hline 2013 & $51,43 \%$ & $\leq 93,52 \%$ & Sehat \\
\hline 2014 & $58,29 \%$ & $\leq 93,52 \%$ & Sehat \\
\hline
\end{tabular}

Sumber: Data Diolah, 2016

Dari tabel 9 di atas hasil perhitungan Rasio BOPO bahwa kinerja keuangan PT. Bank Pembiayaan Rakyat Syariah (BPRS) Muamalat Harkat Sukaraja baik tahun 2013 maupun 2014 dengan kriteria sehat, hal ini disebabkan hasil rasio di bawah 93,52\%.

\section{Pembahasan}

Dari perhitungan rasio likuiditas (LDR), solvabilitas (CAR) dan rentabilitas (ROA dan BOPO) dalam mengukur kinerja keuangan PT. Bank Pembiayaan Rakyat Syariah (BPRS) Muamalat Harkat Sukaraja diketahui bahwa kinerja keuangan rata-rata dalam keadaan sehat, kecuali pada tahun 2013 dinilai dari rasio LDR kinerja keuangan PT. Bank Pembiayaan Rakyat Syariah (BPRS) Muamalat Harkat Sukaraja tidak sehat karena nilai rasio di atas 110\%. Adapun rekapitulasi rasio keuangan PT. Bank Pembiayaan Rakyat Syariah (BPRS) Muamalat Harkat Sukaraja seperti pada tabel 10.

Tabel 10. Rekapitulasi Perhitungan Rasio Keuangan PT. Bank Pembiayaan Rakyat Syariah (BPRS) Muamalat Harkat Sukaraja

\begin{tabular}{|l|c|r|r|l|}
\hline \multirow{2}{*}{ Rasio } & \multirow{2}{*}{ Standar BI } & \multicolumn{2}{c|}{ Hasil Rasio Tahun } & \multirow{2}{*}{ Keterangan } \\
\cline { 2 - 4 } LDR & $\leq 110 \%$ & 2013 & $\mathbf{2 0 1 4}$ & \\
\hline CAR & $>8 \%$ & $143,82 \%$ & $99,73 \%$ & $\begin{array}{l}\text { Tidak } \\
\text { Sehat/Sehat }\end{array}$ \\
\hline ROA & $>1,5 \%$ & $14,49 \%$ & $12,72 \%$ & Sehat \\
\hline BOPO & $\leq 93,52 \%$ & $4,34 \%$ & $2,58 \%$ & Sehat \\
\hline
\end{tabular}

Sumber: Tabel 4,6,8 dan 10, Diolah 2016

Berikut ini kinerja keuangan PT Bank Pundi Indonesia Cabang Bengkulu dari tahun 2013-2014:

a. Loan to Deposit Ratio (LDR)

LDR, adalah rasio antara besarnya seluruh volume pembiayaan yang disalurkan oleh PT. Bank Pembiayaan Rakyat Syariah (BPRS) Muamalat Harkat Sukaraja dengan jumlah penerimaan dana dari berbagai sumber yaitu dalam bentuk giro, tabungan dan deposito. LDR merupakan rasio perbankan yang berhubungan dengan aspek likuiditas dan merupakan suatu pengukuran yang menunjukkan bahwa sumber dana (giro, tabungan dan deposito) mampu menutupi permohonan pembiayaan (loan requests) nasabahnya.

Hasil penelitian pada tahun 2013 penerimaan dana bersumber dari nasabah (giro, tabungan dan deposito) tidak mampu menutupi permintaan pembiayaan. Pada tahun 2013 permintaan pembiayaan yang disalurkan kepada nasabah dalam bentuk pembiayaan Murabahah, Ijrah dan Qord 
sebesar Rp 23.708.502.000 sedangkan total dana yang bersumber dari nasabah dalam bentuk tabungan Wadiah, tabungan dan deposito BPRS Safir, tabungan Mudharabah dan deposito Mudharabah sebesar Rp 16.485.081.000, sehingga kinerja keuangan dari sisi likuiditas yaitu pengukuran LDR tidak sehat karena standar yang ditetapkan oleh Bank Indonesia bahwa nilai LDR tidak boleh lebih dari $110 \%$.

Tidak sehatnya kinerja keuangan PT. Bank Pembiayaan Rakyat Syariah (BPRS) Muamalat Harkat Sukaraja pada tahun 2013 karena tingginya permintaan pembiayaan yang belum sebanding dengan total dana yang dikumpulkan dari masyarakat baik dalam bentuk tabungan, giro maupun deposito.

Sedangkan pada tahun 2014 nilai permintaan pembiayaan Murabahah dan Qord sebesar Rp 20.373.060.000 dapat diimbangi dengan penerimaan dana dari nasabah dalam bentuk tabungan Wadiah, tabungan dan deposito BPRS Safir, tabungan Mudharabah dan deposito Mudharabah yaitu sebesar Rp 20.429.234.000, sehingga kinerja keuangan dari sisi LDR masuk dalam kriteria sehat.

Dari uraian di atas menunjukkan bahwa PT. Bank Pembiayaan Rakyat Syariah (BPRS) Muamalat Harkat Sukaraja dari sisi likuiditas yang ditunjukkan nilai LDR sudah likuid, karena mampu memberikan pembiayaan dari dana yang kumpulkan dari nasabah, dan hal ini masih dalam tahap wajar walaupun pada tahun 2013 PT. Bank Pembiayaan Rakyat Syariah (BPRS) Muamalat Harkat Sukaraja belum mampu mengimbangi antara dana yang dikumpulkan dari masyarakat dalam bentuk tabungan, giro dan deposito dengan dana yang disalurkan kepada masyarakat dalam bentuk pembiayaan.

b. Capital Adequacy Ratio (CAR)

CAR merupakan rasio solvabilitas, yaitu rasio permodalan yang menunjukkan kemampuan bank dalam menyediakan dana untuk keperluan pengembangan usaha serta menampung kemungkinan risiko kerugian yang diakibatkan dalam operasional bank. Capital adequacy adalah kecukupun modal yang menunjukkan kemampuan dalam mempertahankan modal yang mencukupi dan kemampuan manajemen bank dalam dalam mengidentifikasi, mengukur, mengawasi dan mengontrol risiko-risiko yang timbul dan berpengaruh terhadap besarnya modal.

Perhitungan CAR didasarkan pada prinsip bahwa setiap penanaman yang mengandung risiko harus disediakan jumlah modal berdasarkan persentase tertentu terhadap jumlah penanamannya. Kinerja keuangan bank dinyatakan sehat menurut standar Bank Indonesia jika nilai CAR diperoleh minimum $8 \%(>8 \%)$.

Hasil penelitian bahwa pada tahun 2013 dan 2014 PT. Bank Pembiayaan Rakyat Syariah (BPRS) Muamalat Harkat Sukaraja dari nilai CAR, menunjukkan kinerja keuangannya sehat karena nilai rasio di atas $8 \%(14,49 \%$ tahun 2013 dan $12,72 \%$ tahun 2014).

Sehatnya kinerja keuangan PT. Bank Pembiayaan Rakyat Syariah (BPRS) Muamalat Harkat Sukaraja disebabkan nilai modal sendiri sudah cukup baik, sedangkan nilai Aktiva Tertimbang Mmenurut Risiko (ATMR), yaitu penanaman baik dalam bentuk pembiayaan nasabah, investasi pada bank lain baik dalam bentuk penempatan dana, giro maupun deposito ataupun dana yang salurkan pada pihak lain yang memiliki tingkat risiko cukup tinggi, artinya modal sendiri dapat mengimbangi ATMR sehingga hasil perhitungan tahun 2013 CAR sebesar 14,49\% dan tahun 2014 sebesar 12,72\% termasuk dalam kriteria sehat karena nilai rasio di atas $8 \%$.

Besarnya nilai CAR juga disebabkan karena PT. Bank Pembiayaan Rakyat Syariah (BPRS) Muamalat Harkat Sukaraja memiliki struktur modal sendiri yang kuat yang bersumberkan dari modal disetor, cadangan, dan saldo laba rugi tahun berjalan sehingga mampu mengimbangi aktiva yang ditanamkan pada pihak lain yang memiliki tingkat risiko atau Aktiva Tertimbang Menurut Risiko (ATMR).

c. Return On Asset (ROA)

ROA menjadi indikator kinerja suatu bank yang mengukur kemampuan manajemen bank dalam memperoleh profitabilitas. Standar Bank Indonesia menetapkan besarnya ROA minimum di atas 1,5\% (>1,5\%), agar suatu bank dapat dikategorikan sehat. ROA diukur dengan membandingkan laba bersih dengan total aktiva yang tersedia.

Hasil penelitian menunjukkan bahwa PT. Bank Pembiayaan Rakyat Syariah (BPRS) Muamalat Harkat Sukaraja dari nilai ROA baik pada tahun 2013 dan 2014, yaitu 4,34\% dan 2,58\% sedangkan standar Bank Indonesia adalah minimum 1,5\% artinya kinerja keuangan dari sisi perolehan laba adalah sehat. Penurunan nilai ROA pada tahun 2014 menunjukkan perkembangan yang kurang baik, karena besarnya modal sendiri yang dimiliki semakin menurun, penyebabnya karena PT. Bank Pembiayaan Rakyat Syariah (BPRS) Muamalat Harkat Sukaraja pada tahun 2014 terjadi penurunan laba sebesar Rp 168.070.000 (Rp 1.211.204.000-Rp 743.134). 
d. Biaya Operasional terhadap Pendapatan Operasional (BOPO)

BOPO sebagai indikator tingkat kesehatan bank yang menunjukan tingkat efisiensi suatu bank dalam beroperasi, semakin efisiensi suatu bank dalam menjalankan operasinya maka akan semakin memberikan keuntungan dan kinerja yang baik dalam kegiatan operasionalnya.

Hasil penelitian pada tahun 2013 dan 2014 beban operasional bersumber dari adanya beban bonus titipin Wadiah, beban administari dan umum, beban personalia, beban penyisihan penghapusan aktiva produktif dan beban lainnya. Pada tahun 2013 beban operasional PT. Bank Pembiayaan Rakyat Syariah (BPRS) Muamalat Harkat Sukaraja sebesar $\quad$ Rp 3.845.094.000, sedangkan pendapatan operasional sebesar Rp 7.475.641.000, dengan rasio sebesar 51,43\% sehingga kinerja keuangan dari sisi rentabilitas yaitu pengukuran BOPO dengan kriteria sehat dengan standar yang ditetapkan oleh Bank Indonesia bahwa nilai BOPO $\leq 93,52 \%$.

Begitu juga pada tahun 2014 beban operasional sebesar Rp 4.154.197.000 dengan pendapatan operasional yaitu sebesar Rp 7.126.999.000 sehingga nilai rasio BOPO PT. Bank Pembiayaan Rakyat Syariah (BPRS) Muamalat Harkat Sukaraja sebesar 58,29\% sehingga kinerja keuangan dari sisi rentabilitas yaitu pengukuran BOPO sehat dengan standar yang ditetapkan oleh Bank Indonesia bahwa nilai BOPO $\leq 93,52 \%$.

Dari uraian di atas menunjukkan bahwa PT. Bank Pembiayaan Rakyat Syariah (BPRS) Muamalat Harkat Sukaraja dari sisi kinerja keuangan yang ditunjukkan nilai BOPO sehat, karena biaya operasional lebih kecil jika dibandingkan dengan pendapatan operasionalnya. Kinerja keuangan PT. Bank Pembiayaan Rakyat Syariah (BPRS) Muamalat Harkat Sukaraja menunjukkan adanya peningkatan dari segi beban operasional dan terjadi penurunan pendapatan operasionalnya pada tahun 2014 sehingga rasionya naik menjadi 58,29\%. Rasio BOPO yang menjadi indikator rentabilitas suatu bank dalam pengoperasiannya mengalami perkembangan yang berbeda. Karena dengan semakin kecilnya rasio ini akan memberikan keuntungan yang semakin baik terhadap kinerja PT. Bank Pembiayaan Rakyat Syariah (BPRS) Muamalat Harkat Sukaraja.

\section{KESIMPULAN}

Dari hasil penelitian dan perhitungan rasio keuangan pada PT. Bank Pembiayaan Rakyat Syariah (BPRS) Muamalat Harkat Sukaraja dapat ditarik beberapa kesimpulan:

1. Dari sisi rasio likuiditas menunjukan kinerja keuangan berdasarkan perhitungan Loan to Deposit Ratio (LDR) bahwa PT. Bank Pembiayaan Rakyat Syariah (BPRS) Muamalat Harkat Sukaraja selama 2 periode yaitu tahun 2013 tidak sehat, rasio LDR nya melebihi 110\%, pada tahun 2014 masuk dalam kreteria sehat karena nilai rasio di bawah $110 \%$.

2. Dari sisi rasio solvabilitas menunjukan kinerja keuangan berdasarkan perhitungan Capital Adequacy Ratio (CAR) bahwa PT. Bank Pembiayaan Rakyat Syariah (BPRS) Muamalat Harkat Sukaraja selama 2 periode yaitu tahun 2013 dan 2014 sehat karena rasionya di atas $8 \%$.

3. Dari sisi rentabilitas yang menunjukan kinerja keuangan berdasarkan perhitungan rasio Return On Asset (ROA) bahwa PT. Bank Pembiayaan Rakyat Syariah (BPRS) Muamalat Harkat Sukaraja selama 2 periode dengan kriteria sehat karena rasio ROA lebih besar dari 1,5\%.

4. Dari sisi rentabilitas lain dengan menggunakan rasio BOPO menunjukkan kinerja keuangan PT. Bank Pembiayaan Rakyat Syariah (BPRS) Muamalat Harkat Sukaraja selama 2 periode dengan kriteria sehat karena rasionya di bawah 93,52\%, artinya PT. Bank Pembiayaan Rakyat Syariah (BPRS) Muamalat Harkat Sukaraja dapat melakukan efisiensi biaya dengan baik.

\section{Saran}

1. Dari hasil analisis rasio likuiditas yaitu LDR pada tahun 2013 kinerja keuangan tidak sehat tetapi pada tahun 2014 masuk dalam kriteria sehat dan hal ini harus diperhatikan dan ditingkatkan agar pada tahun berikutnya kinerja keuangannya tetap sehat.

2. Dari rasio solvabilitas yaitu rasio CAR baik tahun 2013 maupun 2014 masuk dalam kriteria sehat dan ini harus terus dipertahankan.

3. Dari sisi rasio rentabilitas, yaitu ROA dan BOPO kinerja keuangan sehat, tetapi untuk ROA terjadi penurunan dan hal ini harus diperhatikan karena semakin kecil ROA maka kinerja keuangan semakin tidak sehat. Begitu juga dengan BOPO terjadi kenaikkan nilai rasio, dan hal ini harus diperhatikan karena semakin tinggi nilai rasio BOPO maka kinerja keuangan semakin tidak sehat.

\section{DAFTAR PUSTAKA}

Abdullah, Faizal. 2005. Manajemen Perbankan (Teknik Analisis Kinerja Keuangan Bank). Malang. UMM Press. 
Bank Indonesia.2013. Laporan Keuangan Publiksi Triwulan. http://www.bi.go.id/web/id/

Dendawijaya, Lukman. 2005. Manajemen Perbankan. Edisi Kedua. Jakarta. Ghalia Indonesia.

Dewi AD, Komala. 2014. Analisa Kinerja Keuangan PT Bank Pundi Indonesia Cabang Bengkulu. Skripsi. Bengkulu. Universitas Dehasen.

Fahmi, Irham. 2011. Analisis Laporan Keuangan. Bandung. Alfabeta.

Febriyani, Anita dan Rahadian Zulfadin. 2003. Kajian Ekonomi dan Keuangan: Analisis Kinerja Bank Devisa dan Bank Non-Devisa di Indonesia. Jakarta. Trisakti.

Harahap, Sofyan Syafri. 2010. Analisa Kritis Atas laporan Keuangan. Jakarta. PT. Raja Grafindo Persada.

Hasibuan, S.P Malayu. 2008. Dasar-Dasar Perbankan. Jakarta. Bumi Aksara.

Hasibuan, S.P. Malayu. 2008. Manajemen Dasar, Pengertian dan Masalah. Jakarta. PT. Toko Gunung Agung.

Ikatan Akuntan Indonesia. 2007. Standar Akuntansi Indonesia. Jakarta. Salemba Empat.

Jumingan, 2008. Analisis Laporan Keuangan. Jakarta. Bumi Aksara.

Kasmir. 2012. Analisis Laporan Keuangan. Jakarta. PT. RajawaliGrafindo Persada.

Mardiasmo. 2010. Otonomi dan Manajemen Keuangan Daerah. Yogyakarta. Andi.

Martono dan Agus Harjito. 2007. Analisa Laporan Keuangan. Jakarta. Rineke Cipta.

Prihadi, Toto. 2008. Deteksi Cepat Kondisi Keuangan : 7 Analisis Rasio Keuangan. Jakarta. PPM.

Sadeli, Lili. M. 2008. Dasar-Dasar Akuntansi. Jakarta. PT. Bumi Aksara.

Sugiri, Slamet dan Bogat Agus Riyono. 2008. Akuntansi Pengantar 1. Yogyakarta. AMP YKPN.

Sugiyono. 2010. Metode Penelitian Bisnis. Bandung. Alfabeta.

Suhardjono dan Kuncoro. 2002. Manajemen Perkreditan. Yogjakarta. UPP AMP UKPN.

Sumarti. 2007. Analisis Kinerja Keuangan Pada Syariah Mandiri Jakarta. Skripsi. Surakarta. Universitas Muhammadiyah Surakarta.

Suryabrata, Sumadi. 2009. Metodologi Penelitian. Jakarta. PT. Raja Grafindo Persada.

Tunggal, Amin Widjaja. 2009. Dasar-Dasar Analisis Laporan Keuangan. Jakarta. Rineka Cipta.

Undang-Undang Perbankan Nomor 10 Tahun 1998. Tentang Perbankan. Jakarta. Sinar Grafika.

Winarni, F dan G. Sugiyarso. 2006. Konsep Dasar dan Siklus Akuntansi. Yogyakarta. Media Presindo.

Wirasatama. 2010. Pengukuran Kinerja Organisasi Sektor Publik Dengan Metode Balanced Scorecrd. Fakultas Ekonomi. Universitas Indonesia. 